\title{
Clay addition to sandy soil - effect of clay concentration and ped size on microbial biomass and nutrient dynamics after addition of low $\mathrm{C} / \mathrm{N}$ ratio residue
}

\author{
Shermeen Tahir * and Petra Marschner \\ School of Agriculture, Food and Wine, The University of Adelaide, Adelaide SA 5005, Australia \\ Corresponding author: Shermeen Tahir.*Corresponding author: shermeen.tahir@adelaide.edu.au
}

\begin{abstract}
Addition of clay-rich subsoil to sandy soil has been shown to increase crop production on sandy soils. The added clay is present as peds ranging in size from a millimetre to several centimetre. In thisexperiment clay soil ( $73 \%$ clay) was added to sandy soil (3\% clay) at 10 and $20 \%$ clay w/w as 1,3 and $5 \mathrm{~mm}$ peds. Shoots of young Kikuyu grass (C/N 20) were ground and added at $10 \mathrm{~g} \mathrm{~kg}^{-1}$, and soils were incubated for 45 days at $80 \%$ of water holding capacity. The study confirmed that clay addition to sandy soil increased soil organic carbon retention but decreased cumulative respiration and available P compared to sandy soil alone. Ped size had little effect on respiration and nutrient availability. Over the course of 45 days peds broke down and organic $\mathrm{C}$ was bound to the $<$ $53 \mu \mathrm{m}$ fraction. The greatest proportion of peds and total organic carbon (54-67\%) was in the initially added ped size. The TOC content of $<53 \mu \mathrm{m}$ fraction of initially added peds was $0.38 \%$ and at the end of the experiment (after 45 days) the TOC had increased by 24,19 and $10 \%$ in 1, 3 and 5 mm peds respectively.
\end{abstract}

Keywords: Claying, organic carbon retention, clay peds, sandy soils

\section{Introduction}

Sandy soils have low organic matter content, cation exchange capacity (CEC) and therefore low nutrient retention capacity (Walpola and Arunakumara 2010) and low water holding capacity resulting in low yield. Clay-rich soils on the other hand, have high CEC as well as high water and nutrient retention capacity (Hamarashid et al. 2010). Addition of clay-rich sub- soil to sandy soil has been shown to increase crop production on sandy soils (Davenport et al. 2006; Hall et al. 2010) which is mainly attributed to improved water and nutrient holding capacity (Ismail and Ozawa 2007). The added clay soil may be taken from nearby areas and spread on the surface of the sandy soil. Another option is available on so-called 
duplex soils which have a sandy to sandy loam A horizon and clayey B horizon (Isbell 2002). In these soils, subsoil clay can be mixed into the sandy topsoil by spading or delving. The added clay is present as peds ranging in size from a millimetre to several centimetre thereby creating a heterogeneous soil with patches of clay-rich soil surrounded by sandy soil.

Clay soil addition to sandy soil may increase nutrient availability if the clay soil is nutrient-rich. However, clay subsoils often have low nutrient content (Jobbágy and Jackson 2001; Lawrence et al. 2015). Therefore nutrients have to be added after delving or spading to maximise the benefits of claying. Nutrient addition can be in the form of inorganic fertilisers or organic amendments such as plant residues, manures or compost. Organic amendments have the additional advantage that they can increase soil organic matter content which further improves water and nutrient retention. Decomposition and nutrient release from organic amendments depends on their properties such as $\mathrm{C} / \mathrm{N}$ ratio and particle size. Low $\mathrm{C} / \mathrm{N}$ ratio residue can satisfy the microbial $\mathrm{N}$ demand which results in fast decomposition, early net mineralization and increased microbial biomass (Hoyle and Murphy 2011; Yani et al. 2011). Decomposition rate also depends on accessibility of the organic amendment to soil microbes. Sandy soils have few organic matter binding sites (Strong et al. 2004). Therefore organic amendments are decomposed rapidly. Decomposition rate is lower in clay soils because binding of organic matter to clay surfaces or occlusion within aggregates can reduce organic matter accessibility to microbes (Baldock 2007; Pal and Marschner, 2016).

In a previous study (Tahir and Marschner 2016) with sandy soil amended with 1, 2 or $3 \mathrm{~mm}$ clay peds and faba bean residues ( $\mathrm{C} / \mathrm{N} 37)$, we found that clay addition reduced $\mathrm{N}$ availability but had no consistent effect on cumulative respiration. Ped size had no effect. The experiment described here was conducted to investigate if clay addition has a different effect on respiration and nutrient availability when added as peds with a greater range of sizes $(1,3$ and $5 \mathrm{~mm})$ in presence of plant residue with lower $\mathrm{C} / \mathrm{N}$ ratio $(\mathrm{C} / \mathrm{N}$ 20). The low $\mathrm{C} / \mathrm{N}$ residue was used because the effect of clay addition was stronger with this residue in our previous study (Tahir and Marschner 2017b) due to its high decomposition rate and nutrient release compared to the added faba bean residue.

The aims of this study were to (i) determine the effect of clay addition rate and ped size in residue amended sandy soil on nutrient availability, and (ii) assess breakdown of peds during the experiment and organic $\mathrm{C}$ retention by $<53 \mu \mathrm{m}$ fraction of the peds.

We hypothesised that (i) the smallest peds $(1 \mathrm{~mm})$ will have a greater effect on soil respiration rate and nutrient availability than the $5 \mathrm{~mm}$ peds, and (ii) the larger peds will break down during the experiment into smaller peds with each resulting ped size binding organic carbon.

\section{Materials and Methods}

Clay soil was collected from Waite Campus $\left(34.97^{\circ} \mathrm{S}\right.$, $138.63^{\circ} \mathrm{E}$ ), air-dried, crushed and then sieved through different sieves to achieve peds of 1, 3 and $5 \mathrm{~mm}$. Five $\mathrm{mm}$ peds were collected on a $3.35 \mathrm{~mm}$ sieve after sieving through a $5 \mathrm{~mm}$ (size range $3.35-5 \mathrm{~mm}$ ). The soil that passed through the $3.35 \mathrm{~mm}$ sieve was then sieved through a $2 \mathrm{~mm}$ sieve; the peds on $2 \mathrm{~mm}$ sieve are considered $3 \mathrm{~mm}$ peds (size range 2-3.35 $\mathrm{mm}$ ). The peds passed through $1 \mathrm{~mm}$ sieve and collected on 0.5 $\mathrm{mm}$ sieve are referred to $1 \mathrm{~mm}$ peds (size range 0.5 $1 \mathrm{~mm})$. Sandy soil from Penola $\left(37.37^{\circ} \mathrm{S}, 140.83^{\circ} \mathrm{E}\right)$ was air-dried and sieved ( $2 \mathrm{~mm}$ sieve) to remove organic material/roots. In this area, many farmers have used clay addition to improve crop growth on sandy soils. The clay soil was added to the sandy soil at 10 and $20 \% \mathrm{w} / \mathrm{w}$ as 1,3 and $5 \mathrm{~mm}$ peds. Shoots of young 
Kikuyu grass (Pennisetum clandestinum L.) (C/N 20) were dried in a fan forced oven, ground, sieved to particle sizes $<2 \mathrm{~mm}$ and added a rate of $10 \mathrm{~g} \mathrm{~kg}^{-1}$ to the sandy soil alone and the soil mixes. Total carbon content in young kikuyu shoots was $341 \mathrm{~g} \mathrm{~kg}^{-1}$, total $\mathrm{N}$ and $\mathrm{P}$ were 17.6 and $4.5 \mathrm{~g} \mathrm{~kg}^{-1}$.

After thorough mixing of sand, clay and residues, 30 $\mathrm{g}$ dry weight equivalent of the mixture was placed in PVC cores (radius $1.85 \mathrm{~cm}$ and height $5 \mathrm{~cm}$ ) with a nylon mesh $(7.5 \mu \mathrm{m}$, Australian Filter Specialist) base. The soil was packed to a bulk density of $1.5 \mathrm{~g}$ $\mathrm{cm}^{-3}$. Water content was maintained gravimetrically at $80 \%$ of maximal water holding capacity (WHC) by checking the weight of the cores and adding reverse osmosis (RO) water if necessary. This water content was selected on the basis of a preliminary experiment in which the soil treatments were maintained at different percentage of maximumWHC $(40,50,60$, and $80 \%$ ). Glucose was added as an organic carbon source at $2.5 \mathrm{~g} \mathrm{C} \mathrm{kg}^{-1}$ soil and soil respirationwas measured for one week. Cumulative respiration was highest at $80 \%$ of WHC in all treatments.

Three destructive harvests were carried out on days 15,30 and 45, with four replicates per treatment and harvest time. The cores to be sampled on day 15 were placed in $1 \mathrm{~L}$ glass jars with gas-tight lids equipped with septa for quantification of soil respiration. The remaining cores were placed in a plastic tray covered loosely with a lid. On day 15 , the cores in the jars were removed for analysis and replaced by the cores to be harvested on day 30 . This procedure was repeated on day 30 . The glass jars and plastic trays were incubated at $23^{\circ} \mathrm{C}$ in the dark.

Soil $\mathrm{pH}$ and $\mathrm{EC}$ were determined in a 1:5 soil: water suspension after shaking on an end-over-end shaker at room temperature for one hour (Setia et al. 2013). Particle size distribution was measured by the hydrometer method (Bouyoucos 1936). The maximum water holding capacity (WHC) of the soils was mea- sured by using a sintered glass funnel connected to a 1 $\mathrm{m}$ water column $\left(\Psi_{\mathrm{m}}=-10 \mathrm{kPa}\right)$ (Klute 1986). Total organic carbon in residue was determined by wet digestion and titration (Walkley and Black 1934). For total $\mathrm{N}$ and $\mathrm{P}$, residue was digested with $\mathrm{H}_{2} \mathrm{SO}_{4}$ and $\mathrm{HNO}_{3}$ respectively. Total $\mathrm{N}$ was determined by a modified Kjeldahl method (Vanlauwe et al.1996) and total $\mathrm{P}$ was measured by phosphovanadomolybdate method (Hanson 1950).

Due to the upper detection limit of the infrared gas analyser $\left(2 \% \mathrm{CO}_{2}\right)$ and the decrease in respiration rate over time after residue addition, soil respiration was measured daily for the first 15 days, every second day until day 30 and then every three days until end of the experiment using a Servomex 1450 infra-red analyser as described in (Setia et al.2011). After every measurement the jars were flushed with air using fan, resealed and then remained closed until the next measurement.

At the three destructive samplings soil $\mathrm{pH}$, microbial biomass $\mathrm{C}(\mathrm{MBC}), \mathrm{P}(\mathrm{MBP}), \mathrm{N}(\mathrm{MBN})$, available $\mathrm{N}\left(\mathrm{NH}_{4}\right.$ and $\left.\mathrm{NO}_{3}\right)$ and $\mathrm{P}$ were measured. Microbial biomass $\mathrm{C}$ and $\mathrm{N}$ were measured by chloroform fumigation extraction as described in (Vance et al.1987). Fumigated and un-fumigated samples were extracted with $0.5 \mathrm{M} \mathrm{K}_{2} \mathrm{SO}_{4}$ at a 1:4 soil to extractant ratio. After filtering through Whatman filter paper No. 42 , the filtrate was used to determine microbial biomass $\mathrm{C}$ and N. For Microbial biomass $\mathrm{C}$, the filtrate was subjected to dichromate oxidation (Anderson and Ingram 1993) followed by determination of the organic $\mathrm{C}$ concentration by titration with $0.033 \mathrm{M}$ acidified $\left(\mathrm{NH}_{4}\right)_{2} \mathrm{Fe}\left(\mathrm{SO}_{4}\right)_{2}$. $6 \mathrm{H}_{2} \mathrm{O}$. Microbial biomass $\mathrm{C}$ was calculated by subtracting the organic $\mathrm{C}$ content of fumigated from un-fumigated samples and multiplying the difference by 2.64 (Vance et al. 1987). Microbial biomass $\mathrm{N}$ in the $0.5 \mathrm{M} \mathrm{K}_{2} \mathrm{SO}_{4}$ extracts was measured as $\mathrm{NH}_{4}-\mathrm{N}$ colorimetrically at $685 \mathrm{~nm}$ as described in Willis et al. (1996). To calculate 
microbial biomass $\mathrm{N}$ the difference between fumigated and un-fumigated samples was divided by 0.57 (Moore et al. 2000). Microbial biomass $\mathrm{P}$ and available $\mathrm{P}$ were determined by the anion exchange resin method Kouno et al. (1995) and the $\mathrm{P}$ concentration measured colorimetrically at $712 \mathrm{~nm}$ following Murphy and Riley (1962). For fumigated samples $1 \mathrm{ml}$ hexanol was added along with water before overnight shaking and samples without hexanol were considered as un-fumigated samples, representing available $\mathrm{P}$.

Available $\mathrm{N}$ was extracted by shaking soil with 2 $\mathrm{M} \mathrm{KCl}$ solution at a soil:solution ratio of 1:5 for 1 hour at 200-300 rpm. The suspension was filtered through Whatman filter paper No. 42. Ammonium was measured colorimetrically at $685 \mathrm{~nm}$ following Willis et al. (1996). Nitrate in the $2 \mathrm{M} \mathrm{KCl} \mathrm{ex-}$ tracts was determined colorimetrically at $540 \mathrm{~nm}$ as described in Cavagnaro et al. (2006).

At the end of the experiment the soil mixes were dried and separated through various sieves to retrieve the peds of different sizes; for example where $1 \mathrm{~mm}$ peds were added the soil mixes were passed through a $1 \mathrm{~mm}$ and collected on the 0.5 $\mathrm{mm}$ sieve. The soil with $3 \mathrm{~mm}$ peds was passed successively through $3,2,1 \mathrm{~mm}$ and collected on the $0.5 \mathrm{~mm}$ sieve and soil with $5 \mathrm{~mm}$ peds was passed successively through 5, 3, 2, $1 \mathrm{~mm}$ and collected on the $-0.5 \mathrm{~mm}$ sieve. The retrieved peds of different sizes were separated into $>53 \mu \mathrm{m}$ and $<53 \mu \mathrm{m}$ fractions by wet sieving (Christensen 2001). Organic $\mathrm{C}$ in the $<53 \mu \mathrm{m}$ fraction is referred to as mineral-associated organic C (Kögel-Knabner 2000). For fractionation, the soil was dispersed by shaking with $3 \%$ sodium hexa-metaphosphate at a soil:solution ratio of $1: 13$ for two hours at 200$300 \mathrm{rpm}$. The suspension was sieved through 250 and $53 \mu \mathrm{m}$ sieves and dried overnight at $70^{\circ} \mathrm{C}$. The initial clay peds were also separated into $<53 \mu \mathrm{m}$ and $>53 \mu \mathrm{m}$. The $<53 \mu \mathrm{m}$ fraction was ground and analysed for total organic carbon by wet digestion (Walkley and Black 1934).

The data measured once (initial soil properties, properties of retrieved peds) was analysed by one-way ANOVA. The data measured at different sampling timeswas analysed by repeated measures ANOVA using Genstat $15^{\text {th }}$ edition (VSN Int. Ltd, UK). This showed that the interaction time $\mathrm{x}$ treatment was significant. Tukey's multiple comparison test at $95 \%$ confidence interval was carried out for the time $\mathrm{x}$ treatment interaction.

\section{Results}

The clay soil ( $73 \%$ clay) was alkaline ( $\mathrm{pH} 8.0)$ whereas the sandy soil (96\% sand) was acidic ( $\mathrm{pH}$ 5.4) (Table 1). Organic $C$ and total $N$ were very low in the sandy soil. The available $\mathrm{N}$ and $\mathrm{P}$ concentration in clay soil was $21 \mathrm{mg} \mathrm{kg}^{-1}$ and $0.9 \mathrm{mg}$ $\mathrm{kg}^{-1}$ while in sandy soil it was $4.4 \mathrm{mgkg}^{-1}$ and 1.4 $\mathrm{mg} \mathrm{kg}^{-1}$ soil. Clay soil addition to sandy soil increased maximum water holding capacity two to six-fold with a greater increase at $20 \%$ than at $10 \%$ and with $1 \mathrm{~mm}$ peds compared to the larger peds (Table 2). Clay soil addition had little effect on initial ammonium concentration, but $20 \%$ clay addition reduced available $\mathrm{P}$ concentration compared to sandy soil alone (Table 2). On day 15, the $\mathrm{pH}$ was lower in sandy soil alone than the sand-clay mixtures ( $\mathrm{pH} 8.3$ and 8.7). In all treatments, the $\mathrm{pH}$ was about 0.4 units lower on day 45 than day 15 . 
Table 1. $\mathrm{pH}$, electrical conductivity (1:5), particle size, organic $\mathrm{C}$ and total $\mathrm{N}$ content of clay soil and sandy soil. Values followed by different letters are significantly different $(P \leq 0.05)$.

\begin{tabular}{|c|c|c|c|c|c|c|c|c|}
\hline & \multirow{3}{*}{$\begin{array}{c}\mathrm{pH} \\
(1: 5)\end{array}$} & \multirow{3}{*}{$\begin{array}{c}\mathrm{EC} \\
(1: 5) \\
\mu \mathrm{S} \mathrm{cm}^{-1}\end{array}$} & \multicolumn{3}{|c|}{ Particle size } & \multirow[b]{2}{*}{ Organic $\mathrm{C}$} & \multirow[b]{2}{*}{ Total N } & \multirow{2}{*}{$\mathrm{MBC}$} \\
\hline & & & Sand & Silt & Clay & & & \\
\hline & & & & $(\%)$ & & \multicolumn{2}{|c|}{$\mathrm{g} \mathrm{kg}^{-1}$} & $\mathrm{mg} \mathrm{kg}^{-1}$ \\
\hline Clay soil & $8.0 \mathrm{a}$ & $621 \mathrm{a}$ & 12 & 15 & 73 & $12.7 \mathrm{a}$ & 1.0 & $384 a$ \\
\hline Sandy soil & $5.4 \mathrm{~b}$ & $12 \mathrm{~b}$ & 96 & 1 & 3 & $1.0 \mathrm{~b}$ & nd & $12 \mathrm{~b}$ \\
\hline
\end{tabular}

Table 2. Maximum water holding capacity, ammonium $\mathrm{N}$ and available $\mathrm{P}$ concentrations in sandy soil alone or with 10 and $20 \%$ clay as peds of 1,2 and $3 \mathrm{~mm}(\mathrm{n}=3)$. Values within a column followed by different letters are significantly different $(P \leq 0.05)$.

\begin{tabular}{ccccc}
\hline & $\begin{array}{c}\text { Ped } \\
\text { size } \\
(\mathrm{mm})\end{array}$ & $\begin{array}{c}\text { Water holding } \\
\text { capacity } \\
\left(\mathrm{g}_{\text {water g }}^{-1} \text { soil }\right)\end{array}$ & $\begin{array}{c}\mathrm{NH}_{4}-\mathrm{N} \\
\mu \mathrm{g} \mathrm{g}^{-1} \text { soil }\end{array}$ & $\begin{array}{c}\text { Available P } \\
\mu \mathrm{g} \mathrm{g}^{-1} \text { soil }\end{array}$ \\
\hline Sandy soil & none & $0.02 \mathrm{f}$ & $3.8 \mathrm{c}$ & $9.9 \mathrm{a}$ \\
Sandy soil + $10 \%$ clay & 1 & $0.08 \mathrm{~cd}$ & $4.1 \mathrm{bc}$ & $8.7 \mathrm{~b}$ \\
& 3 & $0.05 \mathrm{e}$ & $4.0 \mathrm{bc}$ & $8.9 \mathrm{ab}$ \\
Sandy soil $+20 \%$ clay & 5 & $0.04 \mathrm{ef}$ & $4.2 \mathrm{bc}$ & $8.9 \mathrm{ab}$ \\
& 1 & $0.13 \mathrm{a}$ & $5.4 \mathrm{a}$ & $7.5 \mathrm{c}$ \\
& 3 & $0.10 \mathrm{bc}$ & $4.3 \mathrm{bc}$ & $7.6 \mathrm{c}$ \\
& 5 & $0.09 \mathrm{~cd}$ & $4.2 \mathrm{bc}$ & $7.5 \mathrm{c}$ \\
\hline
\end{tabular}

Clay soil addition had no consistent effect on $\mathrm{MBC}$ concentration on day 15 , but on day 30 , the MBC concentration was lower with $5 \mathrm{~mm}$ peds than in sandy soil alone (Table 3 ). In contrast on day 45, clay soil addition increased $\mathrm{MBC}$ concentration compared to sandy soil alone, except $5 \mathrm{~mm}$ peds at $20 \%$ clay addition. In the sandy soil alone, the MBC concentration decreased significantly from day 30 to day 45 whereas it did not change over time with $10 \%$ clay. With $20 \%$ clay, the MBC concentration was greater on day 15 than on day 45 . 
Table 3. Microbial biomass $C$ on days 15, 30 and 45 in sandy soil alone or with 10 and 20\% clay as 1, 3 and $5 \mathrm{~mm}$ peds amended with kikuyu residue $(\mathrm{n}=4)$. Values followed by different letters are significantly different (treatment $\mathrm{x}$ time interaction, $P \leq 0.05)$.

\begin{tabular}{|c|c|c|c|c|c|}
\hline & \multirow{3}{*}{$\begin{array}{c}\text { Clay } \\
\text { concentration }\end{array}$} & \multirow{3}{*}{$\begin{array}{l}\text { ped size } \\
(\mathrm{mm})\end{array}$} & \multicolumn{3}{|c|}{ MBC (mg kg ${ }^{-1}$ soil) } \\
\hline & & & \multicolumn{3}{|c|}{ days } \\
\hline & & & 15 & 30 & 45 \\
\hline \multirow{7}{*}{ Sandy soil } & none & none & $335 \mathrm{a}$ & $282 \mathrm{ab}$ & $94 \mathrm{f}$ \\
\hline & $10 \%$ clay & 1 & $255 \mathrm{bc}$ & $241 \mathrm{bcd}$ & $204 \mathrm{cde}$ \\
\hline & & 3 & $227 \mathrm{~cd}$ & $252 \mathrm{bc}$ & $216 \mathrm{cde}$ \\
\hline & & 5 & $227 \mathrm{~cd}$ & $231 \mathrm{~cd}$ & $207 \mathrm{cde}$ \\
\hline & $20 \%$ clay & 1 & $338 \mathrm{a}$ & $249 \mathrm{bcd}$ & 204 cde \\
\hline & & 3 & $334 \mathrm{a}$ & $209 \mathrm{cde}$ & $178 \mathrm{de}$ \\
\hline & & 5 & $274 \mathrm{abc}$ & $153 \mathrm{ef}$ & $150 \mathrm{ef}$ \\
\hline
\end{tabular}

Neither time nor clay soil addition had consistent effect on MBN concentration (data not shown). Microbial biomass $\mathrm{P}$ was also not consistently influenced by clay soil addition, but whereas the MBP concentration did not change in sandy soil alone, it was $50-70 \%$ lower on day 45 than day 15 in clay amended treatments (data not shown).
Compared to sandy soil alone, clay soil addition did not affect available $\mathrm{N}$ concentration on day 15 , but increased it on days 30 and 45 (Table 4). On day 30 in clay amended treatments, the available $\mathrm{N}$ concentration was lower with $5 \mathrm{~mm}$ peds than with the smaller peds. Available $\mathrm{N}$ concentration did not change over time in sandy soil alone, but was generally highest on day 30 in clay amended treatments.

Table 4. Available $\mathrm{N}\left(\mathrm{mg} \mathrm{kg}^{-1}\right.$ soil) on days 15,30 and 45 of sandy soil alone or with 10 and $20 \%$ clay as 1, 3 and $5 \mathrm{~mm}$ peds (amended with kikuyu residue $(\mathrm{n}=4)$. Values followed by different letters are significantly different (treatment $\mathrm{x}$ time interaction, $P \leq 0.05$ ).

\begin{tabular}{|c|c|c|c|c|c|}
\hline & \multirow{3}{*}{$\begin{array}{c}\text { Clay } \\
\text { concentration }\end{array}$} & \multirow{3}{*}{$\begin{array}{c}\text { ped size } \\
(\mathrm{mm})\end{array}$} & \multicolumn{3}{|c|}{ Available $\mathrm{N}$ ( $\mathrm{mg} \mathrm{kg}^{-1}$ soil) } \\
\hline & & & \multicolumn{3}{|c|}{ days } \\
\hline & & & 15 & 30 & 45 \\
\hline \multirow{7}{*}{ Sandy soil } & none & none & $34.5 \mathrm{~h}$ & $34.7 \mathrm{~h}$ & $34.5 \mathrm{~h}$ \\
\hline & $10 \%$ clay & 1 & 45.4 defgh & $55.1 \mathrm{abcd}$ & 44.8 defgh \\
\hline & & 3 & $38.5 \mathrm{fgh}$ & $60.6 \mathrm{abc}$ & 48.8 cdefg \\
\hline & & 5 & $47.6 \mathrm{defg}$ & 43.6 defgh & $62.1 \mathrm{ab}$ \\
\hline & $20 \%$ clay & 1 & $41.2 \mathrm{efgh}$ & $61.0 \mathrm{ab}$ & $47.8 \mathrm{defg}$ \\
\hline & & 3 & $38.0 \mathrm{gh}$ & $66.0 \mathrm{a}$ & 50.1 bcdef \\
\hline & & 5 & 45.0 defgh & 52.3 bcde & 52.4 bcde \\
\hline
\end{tabular}


Clay soil addition reduced available $\mathrm{P}$ concentrations compared to sandy soil alone at all sampling times by $24-$ $50 \%$ with a greater reduction at $20 \%$ clay addition com- pared to $10 \%$ (Table 5). In sandy soil alone, available $\mathrm{P}$ concentration was higher on day 15 than day 45 , but it did not change over time in clay amended treatments.

Table 5. Available $\mathrm{P}\left(\mathrm{mg} \mathrm{kg}^{-1}\right.$ soil) on days 15,30 and 45 of sandy soil alone or with 10 and $20 \%$ clay as 1,3 and $5 \mathrm{~mm}$ peds amended with kikuyu residue $(\mathrm{n}=4)$. Values followed by different letters are significantly different (treatment $\mathrm{x}$ time interaction, $P \leq 0.05)$.

\begin{tabular}{|c|c|c|c|c|c|}
\hline \multirow{4}{*}{ 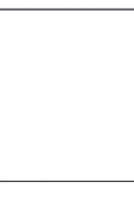 } & \multirow{3}{*}{$\begin{array}{c}\text { Clay } \\
\text { concentration }\end{array}$} & \multirow{3}{*}{$\begin{array}{l}\text { ped size } \\
(\mathrm{mm})\end{array}$} & \multicolumn{3}{|c|}{ Available $\mathrm{P}\left(\mathrm{mg} \mathrm{kg}^{-1}\right.$ soil) } \\
\hline & & & \multicolumn{3}{|c|}{ days } \\
\hline & & & 15 & 30 & 45 \\
\hline & none & none & $39.4 \mathrm{a}$ & $35.0 \mathrm{ab}$ & $33.7 \mathrm{~b}$ \\
\hline \multirow{6}{*}{ Sandy soil } & $10 \%$ clay & 1 & $24.2 \mathrm{c}$ & $25.0 \mathrm{c}$ & $22.7 \mathrm{cde}$ \\
\hline & \multirow{5}{*}{$20 \%$ clay } & 3 & $24.3 \mathrm{c}$ & $24.5 \mathrm{c}$ & $25.6 \mathrm{c}$ \\
\hline & & 5 & $24.6 \mathrm{c}$ & $25.3 \mathrm{c}$ & $22.9 \mathrm{~cd}$ \\
\hline & & 1 & $18.0 \mathrm{def}$ & $18.2 \mathrm{def}$ & $17.0 \mathrm{f}$ \\
\hline & & 3 & $16.6 \mathrm{f}$ & $17.8 \mathrm{def}$ & $17.5 \mathrm{f}$ \\
\hline & & 5 & $16.0 \mathrm{f}$ & $18.3 \mathrm{def}$ & $16.1 \mathrm{f}$ \\
\hline
\end{tabular}

Cumulative respiration over 45 days was significantly higher in sandy soil alone than in treatments with clay added at either $10 \%$ or $20 \%$ (Figure 1 ). Clay concentra- tion and ped size had no consistent effect on cumulative respiration but it was lowest with $20 \%$ clay as $1 \mathrm{~mm}$ peds where it was $36 \%$ lower than sandy soil alone.

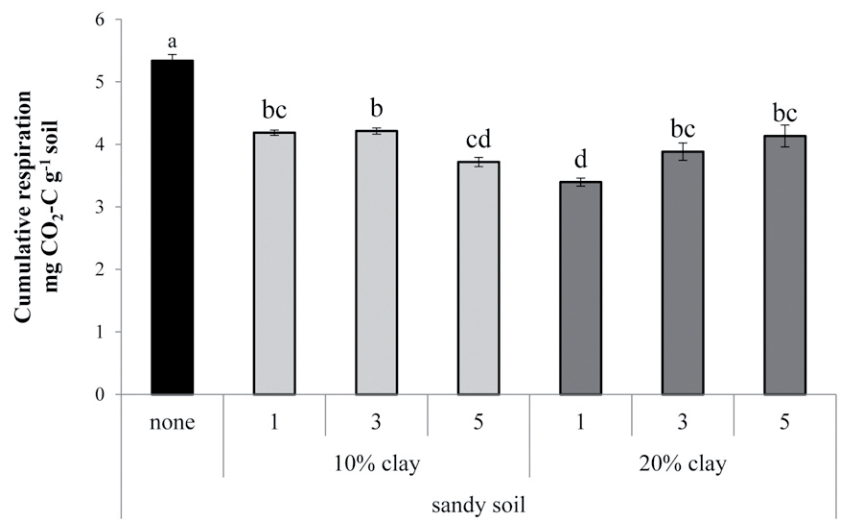

Figure 1. Cumulative respiration over 45 days $\left(\mathrm{mg} \mathrm{CO}_{2}-\mathrm{C} \mathrm{g}^{-1}\right.$ soil) in sandy soil without (none) or with clay soil added as 1, 3 and $5 \mathrm{~mm}$ peds amended with kikuyu (vertical lines indicate standard error, $\mathrm{n}=4$ ). Columns with different letters are significantly different $(P \leq 0.05)$. 
In the treatments with $20 \%$ clay addition, peds were retrieved on day 45 by sieving. Between 75 and $77 \%$ of the added $<53 \mu \mathrm{m}$ particle size was retrieved in peds on day 45. The retrieved peds ranged in size (Table 6). Peds greater than $1 \mathrm{~mm}$ were found in the treatment where $0.5-1 \mathrm{~mm}$ peds had been added, indicating aggregation of peds. On the other hand, in treatments with 3 and $5 \mathrm{~mm}$ peds added, smaller peds were also retrieved. The total weight of the retrieved $<$ $53 \mu \mathrm{m}$ fraction was greater with 3 and $5 \mathrm{~mm}$ peds added than with $1 \mathrm{~mm}$ peds. The greatest proportion of the $<53 \mu$ mparticle size was in the ped size in which they had been added (0.5-1 mm with $1 \mathrm{~mm}$ peds, 3-2 $\mathrm{mm}$ with $3 \mathrm{~mm}$ peds and 5-3 $\mathrm{mm}$ with $5 \mathrm{~mm}$ peds). But the sum of weight of the $<53 \mu \mathrm{m}$ particle size in the other fractions ranged between $38 \%$ and $48 \%$. The TOC of $<53 \mu \mathrm{m}$ fraction of initially added peds was $0.38 \%$ and at the end of the experiment (after 45 days) the increase was 24,19 and $10 \%$ in 1,3 and $5 \mathrm{~mm}$ peds respectively. The TOC concentration of the $<53$ $\mu \mathrm{m}$ fraction was highest in the ped size in which the peds had been added. This is also the case when TOC is expressed as percentage of TOC in peds per core.

Table 6. Properties of the $<53 \mu \mathrm{m}$ fraction after 45 days with $20 \%$ clay as 1,3 or $5 \mathrm{~mm}$ peds, weight, proportion and total organic $C$ content and proportion of total organic $C$ content in retrieved peds $(n=4)$. Values in a column followed by different letters are significantly different $(\mathrm{P} \leq 0.05)$.

\begin{tabular}{|c|c|c|c|c|c|c|}
\hline & $\begin{array}{c}\text { peds } \\
\text { added } \\
(\mathrm{mm})\end{array}$ & $\begin{array}{c}\text { retrieved } \\
\text { peds } \\
(\mathrm{mm})\end{array}$ & $\begin{array}{l}<53 \mu \mathrm{m} \\
\text { fraction } \\
\left(\mathrm{g} \mathrm{core}^{-1}\right)\end{array}$ & $\begin{array}{l}\% \text { TOC of } \\
<53 \mu \mathrm{m}\end{array}$ & $\begin{array}{l}\text { Total TOC } \\
\text { mg core }\end{array}$ & $\begin{array}{c}\% \text { of total } \\
\text { TOC }\end{array}$ \\
\hline \multirow{12}{*}{ 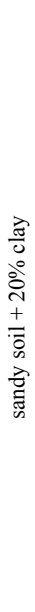 } & \multirow{3}{*}{1} & $>1$ & $1.76 \mathrm{~b}$ & $\begin{array}{l}0.40 \\
\text { bcd }\end{array}$ & 7.04 & 33 \\
\hline & & $<1->0.5$ & $2.84 \mathrm{a}$ & $0.50 \mathrm{a}$ & 14.2 & 67 \\
\hline & & & 4.6 & & 21.2 & \\
\hline & \multirow{4}{*}{3} & $3-2$ & $3.11 \mathrm{a}$ & $0.47 \mathrm{ab}$ & 14.6 & 65 \\
\hline & & $2-1$ & $1.28 \mathrm{c}$ & $0.42 b c$ & 5.4 & 24 \\
\hline & & $<1->0.5$ & $0.89 \mathrm{~d}$ & $0.28 \mathrm{e}$ & 2.5 & 11 \\
\hline & & & 5.28 & & 22.5 & \\
\hline & \multirow{5}{*}{5} & $5-3$ & $2.89 \mathrm{a}$ & $0.42 \mathrm{bc}$ & 12.1 & 54 \\
\hline & & $3-2$ & $1.28 \mathrm{c}$ & $0.34 \mathrm{de}$ & 4.4 & 19 \\
\hline & & $2-1$ & $0.97 \mathrm{~cd}$ & $0.35 \mathrm{cde}$ & 3.4 & 15 \\
\hline & & $<1->0.5$ & $0.84 \mathrm{~d}$ & $0.31 \mathrm{e}$ & 2.6 & 12 \\
\hline & & & 5.98 & & 22.5 & \\
\hline
\end{tabular}

\section{Discussion}

This study showed that clay addition to sandy soil amended with plant residue reduces respiration rate and available $P$ concentration. It also showed that over 45 days, peds can breakdown, but small peds can also be formed. Over the course of the experiment, organic $\mathrm{C}$ was bound to the $<53 \mu \mathrm{m}$ fraction particularly in the ped sizes that were added initially. Ped size had little effect on respiration and nutrient availability. Therefore the first hypothesis (the smallest peds (1 $\mathrm{mm}$ ) will have a greater effect on soil respiration rate 
and nutrient availability than the $5 \mathrm{~mm}$ peds) has to be declined. This is in agreement with our previous study with 1-3 mm peds (Marschner and Tahir 2016) and suggests that the difference in surface area and number between $1 \mathrm{~mm}$ and $5 \mathrm{~mm}$ peds was not large enough to influence decomposability and binding of residues. Further the present study showed that this is the case even when decomposability and nutrient release are higher than in our previous study. The second hypothesis (the larger peds will break down during the experiment into smaller peds with each resulting ped size binding organic matter) can be accepted. On the first day, the respiration rate was lower in sandy soil alone than in clay amended soil which may be due to a low initial microbial biomass in the sandy soil (Table 1). This is probably due to the low TOC content of this soil because microbial biomass is positively correlated with TOC content (Arunachalam 1999; Banerjeeet al. 2006). However, by day 2, the respiration rate was similar in all soils indicating that the small initial microbial biomass in the sandy soil was stimulated by residue addition. From day 6 to day 14 , respiration rates were about two-fold higher in the sandy soil than in clay amended soils which is most likely due to binding of residue particles to the clay peds. Binding to clay reduces organic matter accessibility to microbes (Boldock 2007; Chenu and Plante 2006; Nguyen and Marschner, 2014; Pal and Marschner, 2016). Binding to clay may also explain the lower available P concentration in clay amended soils compared to sandy soil alone (He et al. 1991; Scalenghe et al. 2007).

The retrieval of the peds at the end of the experiment showed that over the course of 45 days peds broke down and organic $\mathrm{C}$ was bound to the $<53 \mu \mathrm{m}$ fraction. The greatest proportion of peds was in the initially added ped size, but between 38 and $48 \%$ of the $<53 \mu \mathrm{m}$ fraction was in other ped sizes which indicates high turnover rate of the peds. The soil was maintained at $80 \%$ of WHC throughout the 45 days, but slight drying followed by rewetting when the water content was adjusted cannot be ruled out. Drying as well as rewetting can cause breakdown of aggregates (Denef et al. 2001b). It could be expected that the TOC content is greater in small compared to larger peds because of their higher surface area to volume ratio (Mayer 1994). However, this was not the case in this experiment. The TOC content was greatest in the ped size added initially which had a longer time of contact with the added residues than peds formed during the experiment. This suggests that in this experiment, time of contact may be more important than the surface area to volume ratio with respect to TOC binding to the $<53 \mu \mathrm{m}$ fraction. The surface area to volume ratio may become more important later when the added residue has been decomposed.

The finding that when $1 \mathrm{~mm}$ peds were added about $38 \%$ of the $<53 \mu \mathrm{m}$ fraction was retrieved in the $>1$ $\mathrm{mm}$ size class suggests that there was aggregation of smaller peds during the experiment. It cannot be ruled out that aggregation also occurred in the treatments where 3 and $5 \mathrm{~mm}$ peds were added. But in these treatments, ped breakdown dominated ped formation. A smaller amount of the $<53 \mu \mathrm{m}$ fraction was retrieved at the end of the experiment in the treatment with $1 \mathrm{~mm}$ than in those with 3 and $5 \mathrm{~mm}$ peds. This indicates that with $1 \mathrm{~mm}$ peds added, more of the < $53 \mu \mathrm{m}$ fraction was in particle sizes $<0.5 \mathrm{~mm}$ and therefore not considered in this experiment.

Breakdown and formation of peds may explain why soil respiration and nutrient availability were not influenced by the size of initially added peds. Ped size may have a greater effect if the range of ped sizes added is greater as it is after clay addition in the field where ped diameters can range from a few $\mathrm{mm}$ to $\mathrm{cm}$. However, adding larger peds would not have been possible in our experimental setup. 


\section{Conclusion}

The study confirmed that clay addition to sandy soil increases soil organic carbon retention compared to sandy soil alone. It also showed substantial ped breakdown as well asformation of larger peds over 45 days. The newly formed peds can also influence nutrient cycling and bind organic $\mathrm{C}$ which may explain why ped size did not have a consistent effect on soil respiration and nutrient availability. Field experiments are needed to assess ped breakdown and organic $\mathrm{C}$ binding in relation to ped size over longer periods of time.

\section{Acknowledgement}

The authors would like to acknowledge Amanda Schapel, Rural Solutions SA for providing the sandy soil. Shermeen Tahir thanks The University of Adelaide for the International Postgraduate Research Scholarship (IPRS).

\section{References}

Anderson, J. M., Ingram. J. S. I. 1993. Tropical Soil Biology and Fertility, A Handbook of Methods $2^{\text {nd }}$ edn. CAB International, Wallingford, UK

Arunachalam, K., Arunachalam, A., Melkania, N. P. 1999. Influence of soil properties on microbial populations, activity and biomass in humid subtropical mountainous ecosystems of India. Biology and Fertility of Soils. 30, 217-223.

Baldock, J.A. 2007. Composition and cycling of organic carbon in soils. In: Nutrient Cycling in Terrestrial Ecosystems. Springer, 1-36 p.

Banerjee, B., Aggarwal, P. K., Pathak, H., Singh, A. K., Chaudhary, A. 2006. Dynamics of organic carbon and microbial biomass in alluvial soil with tillage and amendments in rice-wheat sys- tems. Environmental Monitoring and Assessment 119,173-189.

Bouyoucos, G.J. 1936. Directions for making mechanical analyses of soils by the hydrometer method. Soil Science. 42, 225-230.

Cavagnaro, T.R., Jackson, L. E., Six, J., Ferris, H., Goyal, S., Asami, D., Scow, K. M. 2006. Arbuscular mycorrhizas, microbial communities, nutrient availability and soil aggregates in organic tomato production. Plant and Soil. 282, 209-225.

Chenu, C., Plante, A. F. 2006. Clay-sized organo-mineral complexes in a cultivation chronosequence: revisiting the concept of the "primary organo-mineral complex' European Journal of Soil Science. 57, 596-607

Christensen, B.T. 2001. Physical fractionation of soil and structural and functional complexity in organic matter turnover. European Journal of Soil Science. 52, 345-353.

Davenport, D., Wilhelm, N., Doudle, S. 2006. Clay spreading and delving on Eyre Peninsula. Government of South Australia, SARDI, GRDC, South Australia.

Denef, K., Six, J., Paustian, K., Merckx, R.2001b. Importance of macro-aggregate dynamics in controlling soil carbon stabilization: shortterm effects of physical disturbance induced by dry-wet cycles. Soil Biology and Biochemistry. 33, 2145-2153.

Hadas, A.,Kautsky, L., Goek, M., Kara, E. E. 2004. Rates of decomposition of plant residues and available nitrogen in soil, related to residue composition through simulation of carbon and nitrogen turnover. Soil Biology Biochemistry. 36, 255266.

Hall, D.J.M., Jones, H., Crabtree, W., Daniels, T.2010. Claying and deep ripping can increase crop yields and profits on water repellent sands with marginal fertility in Southern Western Australia. AustralianJournal of Soil Research. 178-180. 
Hamarashid, N., Othman,M., Hussain, M. 2010. Effects of soil texture on chemical compositions, microbial populations and carbon mineralization in soil. Egyptian Journal of Experimental Biology $6,59-64$.

Hanson, W.C. 1950. The photometric determination of phosphorus in fertilizers using the phosphovanado-molybdate complex. Journal of Science Food Agriculture. 1, 172-173.

He, Z.L., Yuan, K. N., Zhu, Z. X.1991. Physico-chemical indexes for assessing plant availability of $\mathrm{P}$ in soil. Acta Pedologica Sinica. 28,302-308.

Hoyle, F.C.,Murphy, D. V. 2011. Influence of organic residues and soil incorporation on temporal measures of microbial biomass and plant available nitrogen. Plant and Soil. 347, 53-64.

Isbell, R. 2002. The Australian Soil Classification. Australian Soil and Land Survey Handbooks, CSIRO Publishing, Melbourne

Ismail, S.M., Ozawa, K. 2007. Improvement of crop yield, soil moisture distribution and water use efficiency in sandy soils by clay application. Applied Clay Science. 37, 81-89.

Jobbágy E.G., Jackson, R. B. 2001. The distribution of soil nutrients with depth: Global patterns and the imprint of plants. Biogeochemistry.53, 51-77.

Klute, A. 1986. Water-retention. In: Methods of soil analysis. Part 1 Physical and mineralogical methods. American Society of Agronomy-Soil Science, Madison, WI, pp 635-660.

Kögel-Knabner, I. 2000. Analytical approaches for characterizing soil organicmatter. Organic Geochemistry. 31, 609-625.

Kouno, K., Tuchiya, Y., Ando, T. 1995. Measurement of soil microbial biomass phosphorus by an anion exchange membrane method. Soil Biology and Biochemistry. 27, 1353-1357.
Lawrence, C. R., Harden, J. W., Xu, X., Schulz, M S.,Trumbore, S. E. 2015. Long-term controls on soil organic carbon with depth and time: A case study from the Cowlitz River Chronosequence, WA USA Geoderma. 247-248, 73-87.

Mayer, L.M. 1994. Surface area control of organic carbon accumulation in continental shelf sediments. Geochimica et Cosmochimica Acta. 58, 1271-1284.

Moore, J., Klose, S.,Tabatabai, M. 2000. Soil microbial biomass carbon and nitrogenas affected by cropping systems. Biology andFertility of Soils. 31, 200-210.

Murphy, J., Riley, J.P. 1962. A modified single solution method for the determination of phosphate in natural waters. Analytica Chimica Acta. 27, 31-36.

Nguyen, T. T., Marschner. 2014. Respiration in mixes of sandy and clay soils: influence of clay type and addition rate. Journal of Soil Science and Plant Nutrition. 14 (4), 881-887.

Pal, S., Marschner, P. 2016. Influence of clay concentration, residue $\mathrm{C} / \mathrm{N}$ and particlesize on microbial activity and nutrient availability in clay amended sandy soil. Journal of Soil Science and Plant Nutrition. 16 (2), 350-361.

Scalenghe, R., Edwards, A. C., Barberis, E. 2007. Phosphorus loss in over fertilized soils: The selective $\mathrm{P}$ partitioning and redistribution between particle size separates. European Journal of Agronomy. 27, 72-80.

Setia, R., Marschner, P., Baldock, J., Chittleborough, D., Smith, P., Smith, J. 2011. Salinity effects on carbon mineralization in soils of varying texture. Soil Biology and Biochemistry. 43, 1908-1916.

Setia, R., Rengasamy, P., Marschner, P. 2013. Effect of exchangeable cation concentration on sorption and desorption of dissolved organic carbon in saline soils. Science of Total Environment. 465, 226-232. 
Strong, D. T., De Wever, H., Merckx, R., Recous, S. 2004. Spatial location of carbon decomposition in the soil pore system. European Journal of Soil Science. 55, 739-750.

Tahir, S.,Marschner, P. 2016. Clay amendment to sandy soil - effect of clay concentration and ped size on nutrient dynamics after residue addition. Journal of Soils and Sediments. 16, 2072-2080.

Tahir, S., Marschner, P. 2016. Clay addition to sandy soil-influence of clay type and size on nutrient availability with residues differing $\mathrm{C} / \mathrm{N}$ ratio amendment. Pedosphere (in press)

Vance, E.D., Brookes,P. C., Jenkinson, D. S. 1987. An extraction method for measuring soil microbial biomass C. Soil Biology and Biochemistry. 19, 703-707.

Vanlauwe, B., Nwoke, O. C., Sanginga, N., Merckx, R. 1996. Impact of residuequality on the $\mathrm{C}$ and $\mathrm{N}$ mineralization of leaf and root residues of three agroforestry species. Plant and Soil 183, 221-231.

Walkley, A., Black, L. A. 1934. An examination of the Degtjareff method for determining soil organic matter, and a proposed modification of the chromic acid titration method. Soil Science $37,29-38$
Walpola, B.C., Arunakumara, K. K. I. U. 2010. Decomposition of Gliricidia leaves: the effect of particle size of leaves and soil texture on carbon mineralization. Tropical Agriculture Research. $13,19-23$

Willis, R., Montgomery, M., Allen, P. 1996. Improved Method for manual, colorimetric determination of total Kjeldahl nitrogen using salicylate. Journal of Agricultural Food Chemistry. 44,1804-1807.

Yaghi, N., Hartikainen, H. 2014. Enhancement of phosphorus sorption onto light expanded clay aggregates by means of aluminum and iron oxide coatings. Chemosphere. 103, 359-359.

Yanni, S.F., Whalen, J. K., Simpson,M. J., Janzen, H. H. 2011. Plant lignin and nitrogen contents control carbon dioxide production and nitrogen mineralization in soils incubated with Bt and nonBt corn residues. Soil Biology and Biochemistry. 43, 63-69. 